capillaries are accompanied by compensatory and adaptive ones. This is manifested by the activation of the transport of substances, both transendothelial and paracellular. The increase of microvesiculation processes, which is reflected in the quantitative density of micropinocytotic vesicles in this age group, may be caused by several factors: this is the redistribution in the molecular composition of the plasma membranes as well as the accumulation of calcium ions in the cytoplasm, and the activation of lipid peroxide oxidation processes. All these rearrangements are characteristic for arterial hypertension and can play certain role in the changes in transcytosis, which in this period of observation, nevertheless, are compensatory oriented. Changes in intercellular transport are ultrastructurally manifested by increase of gaps in some inter-endothelial junctions. It is believed that this occurs in those junctions that are mechanically weak, that is, open junctions, due to changes in hemodynamics or osmolarity of the surrounding fluid in case of $\mathrm{Na}^{+} / \mathrm{Ca}^{2+}$ exchange disorder in arterial hypertension rats [11-13].

Consequently, in the development of arterial hypertension, an important role is played by endothelium dysfunction [14-17]. The exchange of substances is in direct dependence on the permeability of blood capillaries. One of its main pathways is transcytosis, the structural expression of which is micropinocytotic vesicles [1]. Phenotypic peculiarity of myocardial blood capillaries is the predominance of processes of micropinocytosis over biosynthetic, that is, the basic structures that are represented in the endothelium of these micro-vessels are micropinocytotic vesicles. The quantitative representation of these structures varies depending on age and pathological state and may be an indicator of both the stages of differentiation and the degree of damage [19].

\section{CONCLUSIONS}

In myocardial capillaries of young (45-day) arterial hypertension rats compensatory-adaptive changes are manifested by activation of biosynthetic processes in endothelial cells, with a slight increase in the micropinocytotic vesicles quantitative density. Signs of destructive-dystrophic processes are edema and lysis of the endothelial cell cytoplasm, which do not become widespread in this period of observation.

In the blood capillaries of the myocardium of sexually mature (100-day) arterial hypertension rats the destructive-degenerative changes increase with the preservation of signs of compensatory processes. Reducing number of capillaries is offset by increase in the number of micropinocytotic vesicles.

\section{REFERENCES}

1. Dzyak G.V., Goncharov 0.S. Application of selective $\beta$-adrenoblocker bisoprolol in the treatment of patients with chronic heart failure. Cardiologist practice. 2006; 4(1):1-5.

2. Dovgan R.S., Stechenko L.0., Zagorodniy M.I., Chekman I.S. Morphofunctional features of the cardiac myocardial ultrastructure of rats with spontaneous arterial hypertension. Visn morphology. 2007; 13(2): 255-260.
3. Antonov Ye.V., Alexandrovich Yu.V., Seryapina A.A., Klimov L.O., Markel A.L. Stress and arterial hypertension: ISIAH rat strain. Vavilovskii Zhurnal Genetiki i Selektsii - Vavilov Journal of Genetics and Breeding. 2015; 19(4): 455-459. DOI 10.18699/VJ15.060

4. Chuhray S.M., Lavrynenko V.E., Kaminsky R.F., Dzevulska I.V., Malikov 0.V., Kovalchuk 0.I., Sokurenko L.M. Morphofunctional status of cardiovascular system of rats with congenital hypotireosis. Wiad Lek. 2019; 72(2): 229-233.

5. Karupu V.Ya. Electron microscopy. K.: Vishcha School, 1984: 208 p.

6. Chuhray S.M., Lavrynenko V.E., Kaminsky R.F., Ustymenko 0.S., Dzevulska I.V., Matkivska R.M, Kovalchuk 0.I., Holubchenko 0., Sokurenko L.M. The influence of drug treatment on cardio-vascular system of the rats with congenital hypothyroidism. Wiad Lek. 2019;71(7):1300-1303.

7. Kuklinska A.M., Mroczko B., Musial W.J., Usowicz-Szarynska M., Sawicki R., Borowska H., Knapp M., Szmitkowski M. Diagnostic biomarkers of essential arterial hypertension: the value of prostacyclin, nitric oxide, oxidized-LDL, and peroxide measurements. Int Heart J. 2009; 50(3):341-351.

8. Versari D., Daghini E., Virdis A., Ghiadoni L., Taddei S. Endotheliumdependent contractions and endothelial dysfunction in human hypertension. Br. J. Pharmacol. 2009; 157(4): 527-536.

9. Kozyreva T.V., Loshakina S.V., Tuzikov F.V. Changes in the composition of blood lipoproteins under the influence of cold effects in normotensive and hypertensive rats. Patol Physiologist Experiment therapy 2006; 1 : 20-22.

10. Kozyreva TV, Loshakina S.V., Tuzikov F.V. Changes in the composition of blood lipoproteins under the influence of cold exposure in normotensive and hypertensive rats. Patol. Fiziol. Experiment. therapy. 2007;13( 2): 255-260.

11. Bhattacharjee A.K., Nagashima T., Kondoh T., Tamaki N. The effects of the $\mathrm{Na}+\mathrm{Ca} 2+$ exchange blocker on osmotic blood-brain barrier. Brain Res. 2001; 900: 157-162.

12. Ueno M. Sakamoto H., Liao Y., Onodora M., Huang C., Miyanak H., Nakagawa T. Blood-brain barrier disruption in the hypothalamus of young adult spontaneously hypertensive rats. Histochem. Cell Biol. 2004; 122: 131-137.

13. Al-Sarraf H. Time Course of Hyperosmolar Opening of the Blood-Brain and Blood-CSF Barriers in Spontaneously Hypertensive Rats. J.Vascular Res. 2007; 44(2): 99-109.

14. Kuzminova N.V., Serkova V.K. The effect of antihypertensive drugs on endothelial dysfunction in patients with hypertension. Ukr. honey. Chasopis. 2008; 2 (64) III/IV: 66-74.

15. Sobolev G.N., Rogoza A.N., Shumilina M.V., BuziashviliYu.I., KarpovYu.A. Endothelial dysfunction in arterial hypertension: vasoprotective effects of b-blockers of a new generation. Cardiology. 2001; 9 (18): 754 -757.

16. Boulanger C.M. Secondary endothelial dysfunction: hypertension and heart failure. Mol. Cell Cardiol. 1999; 31(1): 39-49.

17. Taddei S. Ghiadoni L., Virdis A., Versari D., Salvetti A. Mechanisms of endothelial dysfunction: clinical significance and preventive nonpharmacological therapeutic strategies. Curr. Pharm. Des. 2003; 9: 2385-2402.

18. Karaganov J.L., Mironov V.A., Mironov A.A. Reactivity of the vascular endothelium. Vascular endothelium. Ed. V.V. Kupriyanov, I.I. Bobrik, Ya.L.Karaganova.- Kiev: Health, 1986; 183-199.

19. Stechenko L.O., Zagorodniy M.I., Dovgan R.S., Chekman I.S. Morphofunctional features of the cardiac myocardial ultrastructure of rats with spontaneous arterial hypertension. Visn. morphology 2007; 13(2):255-260. 


\section{Acknowledgements}

The authors would like to thank the employees of the Scientific Research Institute Experimental And Clinical Medicine (Institute of Pathologists Problems) at Bogomolets National Medical University prof. L.O. Stechenko and T.P.Kuftyreva.

\section{ORCID and contributionship:}

Svetlana M. Chuhray - 0000-0001-7431-7375

Viktoria E. Lavrynenko -0000-0002-2570-1271

Rostyslav F. Kaminsky-0000-0001-5744-7581, C,E

Iryna V. Dzevulska - 0000-0002-8043-6626 $6^{E, F}$

Oleksandr V. Malikov - 0000-0002-8113-2974

Ruzhena M. Matkivska - 0000-0002-4082-2899E

Larysa B. Shobat - 0000-0002-8592-520X ${ }^{F}$

Oleksandr I. Kovalchuk - 0000-0002-6311-3518 ${ }^{F}$

Liudmyla M. Sokurenko - 0000-0002-6870-2290

\section{Conflicts of interest:}

Authors declare no conflict of interest.

\section{CORRESPONDING AUTHOR}

Liudmyla M. Sokurenko

Bogomolets National Medical University

Kyiv, Ukraine

e-mail: I-sokurenko@i.ua

Received: 26.07.2019

Accepted: 30.12.2019

A - Work concept and design, B - Data collection and analysis, C - Responsibility for statistical analysis,

D-Writing the article, $\mathbf{E}$-Critical review, $\mathbf{F}$ - Final approval of the article 


\title{
STATISTICAL ANALYSIS OF THE CHRONIC GASTRITIS IN STUDENTS
}

DOI: 10.36740/WLek202002129

\author{
Aleksandr V. Kharchenko ${ }^{1}$, Nataliya V. Kharchenko ${ }^{2}$, Petro M. Makarenko ${ }^{3}$, Lyudmyla M. Sakharova ${ }^{3}$, \\ Pavlo V. Khomenko ${ }^{4}$, Olga V. Kvak ${ }^{4}$ \\ 'PETRO MOHYLA BLACK SEA NATIONAL UNIVERSITY, MYKOLAIV, UKRAINE \\ ¿UKRAINIAN MEDICAL DENTAL ACADEMY, POLTAVA, UKRAINE \\ 3POLTAVA STATE AGRARIAN ACADEMY, POLTAVA, UKRAINE \\ ${ }^{4}$ POLTAVA V.G. KOROLENKO NATIONAL PEDAGOGICAL UNIVERSITY, POLTAVA, UKRAINE
}

\begin{abstract}
The aim: The aim of the study is a statistical analysis of the mucosa of the stomach affected by Helicobacter pylori in young people studying at the university.

Materials and methods: The work contains the results of the study of chronic gastritis of type B in university volunteer students. The study was attended by students of 1-4 courses, aged 17 to 25 years, a total of 50 people. Among them were 28 men and 22 women.

Results: Various forms of chronic gastritis were found in the mucosa of the topographic-anatomical sections of the stomach, $90 \%$ of which were associated with Helicobacter pylori (HP). In all departments there is a different amount of common forms of chronic gastritis. In the pyloric section only atrophic gastritis was detected $-31.0 \pm 8.5$. Atrophic gastritis was also dominant on the lesser curvature $-32.3 \pm 7.8$, but its forms were significantly $(p<0.5)$ less pronounced than in the pyloric section. In the area of the body, the above variants of chronic gastritis were found in $34.3 \pm 8.7$ cases, and the majority were flat erosive gastritis $51.0 \pm 9.3$.

There is a tendency to reduce the degree of bacterial contamination of the gastric mucosa from its pyloric section and the lesser curvature to the walls of the body. With a decrease in the degree of bacterial contamination of the gastric mucosa, the degree of leukocyte infiltration also decreases.

Between the degree of contamination of the mucous membrane of Helicobacter pylori and the degree of leukocyte infiltration of the mucous membrane, the Pearson correlation coefficient is $r_{x y}-0,935$, the correlation is very strong, the coefficient of determination is $D=r_{x y} \wedge 2-0,874$, the statistically significant dependence on the probability is 0.99 . Conclusions: Atrophic or hyperplastic gastritis associated with HP is found in the gastric mucosa, respectively, $90 \%$ of cases. The degree of bacterial contamination correlates with the degree of leukocyte infiltration of the gastric mucosa. Atrophic or hyperplastic gastritis Helicobacter pylori-associated is a common disease of people in young and working age.
\end{abstract}

KEY WORDS: Helicobacter pylori, gastritis, leukocyte infiltration, gastric mucos

\section{INTRODUCTION}

According to the World Health Organization, more than fifty percent of the world's population suffer from diseases of the gastrointestinal tract. One of the most striking and often encountered with these ailments is gastritis. It is an inflammation of the mucous membrane of the stomach walls. Chronic gastritis is a chronic inflammation of the mucous membrane of the stomach with the restructuring of its structure and progressive atrophy, impaired motor, secretory and endocrine functions [1] But, despite the relatively high level of research on this disease, numerous aspects of pathogenesis and morphogenesis, the treatment and watching clinic are not enough.

According to statistics, about $70 \%$ of the population of Ukraine, including children, suffer from various forms of chronic gastritis.

Chronic atrophic gastritis is usually an asymptomatic condition, it is of great importance that it is a precancerous condition and turns into cancer in a certain group of patients.
There is atrophic gastritis in patients with Helicobacter pylori infection - type B (bacterial), as well as the autoimmune type. The autoimmune type is rare and affects a certain number of people of all nationalities [2].

Spiral bacteria were found in the human stomach at the end of the maidens of the fifteenth century, they were first described by G. Bizzozero in 1893 [3]. After that, occasional separate scientific works appeared indicating the presence of spiral microorganisms in the human stomach. But Australian researchers in 1983 for the first time conducted a detailed study of these bacteria [4]. The discovery of Helicobacter pylori allowed to consider the infectious theory of the origin of peptic ulcer at a new level. But the new discovery drew the attention of scientists from all over the world who are working on oncogenesis in the stomach. Normal gastric mucosa has powerful mechanisms that preserve the proliferation zone from the action of potential carcinogens. Elements of such a protective barrier are universal. They protect cell divisions from both the action of carcinogens and other factors. Almost all of them can be destroyed 
by Helicobacter pylori [5] Worldwide, $H$. pylori infection is very common and contributes to the formation of first class malignant tumors in a large number of patients who develop stomach cancer as a result [6]. The pathogenesis of the autoimmune type involves antibody-induced loss of parietal cells, leads to achlorhydria, and antibody-mediated loss of intrinsic factor causing pernicious anemia. Patients with atrophic gastritis associated with $H$. pylori infection should be treated with antibiotics in order to destroy microorganisms. Diagnosis Helicobacter pylori infection is based on endoscopy with gastro biopsy and the release of microorganisms. The condition for solving a diagnostic problem, the application of molecular biological methods in conjunction with the morphological studies of the gastric mucosa [7-10].

\section{THE AIM}

The purpose of the study is a statistical analysis of the state of the gastric mucosa of the affected Helicobacter pylori in young people studying at the university.

\section{MATERIALS AND METHODS}

The work contains the results of the study of chronic gastritis of type B in students of our university volunteers. The study was attended by students of 1-4 courses aged 17 to 25 years, only 50 people. Among the latter were 28 men and 22 women. In them, by agreement, gastrobiopsies were taken in the endoscopy room of the regional hospital for further study. Ethics and bioethics were respected.

Ethics Commission of the Poltava National Pedagogical University named after V.H. Korolenko noted that the study was carried out without violations by the students studied. The latter were fully aware of the methods and scope of research. The survey has been conducted voluntarily and anonymously in accordance with the requirements and standards, model regulations on ethics issues of the Ministry of Health of Ukraine No. 690 of September 23, 2009.

The colonization of Helicobacter pylori infection to the condition of the gastric mucosa was studied on semi-thin sections made of epoxy blocks (eponym - 812). Gastrobioptatas of the gastric mucosa for the study were taken from the pyloric region of the lesser curvature and body of the stomach.

The fixative was a $10 \%$ neutral formalin solution or $4 \%$ cold glutaraldehyde solution in phosphate buffer at $\mathrm{pH} 7.4$ [11]. The quality assessment of the obtained samples was carried out using a stereoscopic microscope. After a leak in the epoxy resin, the tissue blocks were placed in a capsule filled with resin, where the polymerization of the material was carried out gradually at a temperature of $35^{\circ}, 45^{\circ}$ and $60^{\circ} \mathrm{C}$ for 24 hours [12].

With paraffin or epoxy units of different topografoanatomicheskom parts of the gastric mucosa in a microtome MPS- 2 received slices, which were placed in a tray for slices and stained with haematoxylin and eosin and toluidine blue (to Helicobacter infection pylori study) by conventional schemes and placed in Canada balsam [12].
A freshly prepared and filtered $0.1 \%$ solution of toluidine blue on phosphate buffer ( $\mathrm{pH} 7.4)$ was used as a dye. In the remaining stained sections, except for the epithelial components, the dye allows to detect the bacteria Helicobacter pylori.

When establishing the forms of chronic gastritis, morphological classification[13] and classification of chronic gastritis, adopted at the 9th International Congress of Gastroenterologists in Sydney (1990), were used. The following morphological forms of chronic gastritis were distinguished:

1) by etiology: an autoimmune associated with pyloric Helicobacterium (HP); special form (eosinophilic, granulomatous) by topographic characteristic: antral (pyloroduodenitis) fundal (of the body of the stomach); 2 ) according to the degree of morphological signs: no changes; flat erosive; atrophic; hyperplastic;

3) by the nature of gastric juice: with preserved or increased secretion; with secretory insufficiency.

To quantify the degree of contamination of the gastric mucosa of Helicobacter pylori, bacteria were counted in a field of view $\times 600$. A weak (up to 20 bacteria), moderate (up to 50 bacteria) and high (more than 50 bacteria) degree of contamination was isolated. In this field of view, a semi-quantitative assessment of the degree of leukocyte infiltration of the gastric mucosa was also performed. When rare disseminated polymorphonuclear leukocytes were found in inflammatory infiltrates and in the layer of pathogenic epithelium, the degree of leukocyte infiltration was assessed as poorly expressed and, as fields, as expressed.

When conducting morphometric studies, recommendations were used that were presented in the works of $\mathrm{C}$. Taşcă [14], and G. Avtandilov [15]. The results obtained from morphometric studies were statistically processed using standard methods of variation statistics. The significance of differences in the average compared indicators was assessed by Student's criteria $(\mathrm{t})$. The difference between comparable values was considered significant, as that the permissible error ( $\mathrm{p}$ ) was less than 0.05 .

\section{RESULTS AND DISCUSSION}

Various forms of chronic gastritis were found in the mucosa of the topographic-anatomical regions of the stomach, $90 \%$ of which were associated with Helicobacter pylori (HP). In all the vosplaying cases, different volume has developed forms of chronic gastritis (Table 1). In the pyloric department only atrophic gastritis was detected $31.0 \pm 8.5$. In the pyloric section only atrophic gastritis was detected $-31.0 \pm 8.5$.

In the area of the body, the above variants of chronic gastritis were found in $34.3 \pm 8.7$ cases, and the majority were flat erosive gastritis gastritis $51.0 \pm 9.3$.

In the mucous membrane of the multi-row epithelium with the formation of bushes-like structures.

The brushes are filled with mucus and are expelled by the cylindrical epithelium. The thickness of the mucous membrane incendiary infiltrated. Coloring with hematoxylin-eosin. Increase 180 . 
Table 1. The frequency of various forms of chronic gastritis in the topographic-anatomical regions of the stomach in percent (\%)

\begin{tabular}{cccc}
\hline \multirow{2}{*}{ Stomach sections } & \multicolumn{3}{c}{ Gastritis form } \\
\cline { 2 - 4 } & Flat erosive gastritis & Atrophic gastritis & Hyperplastic gastritis \\
\hline P & - & $31,0 \pm 8,5$ & - \\
\hline SC & $10,0 \pm 6,1$ & $32,3 \pm 7,8$ & $6,7 \pm 4,6$ \\
\hline B & $51,0 \pm 9,3$ & $34,3 \pm 8,7$ & $11,3 \pm 6,3$ \\
\hline
\end{tabular}

$\mathrm{P}$ - pyloric section; $\mathrm{SC}$ - small curvature; $\mathrm{B}$ - body of the stomach.

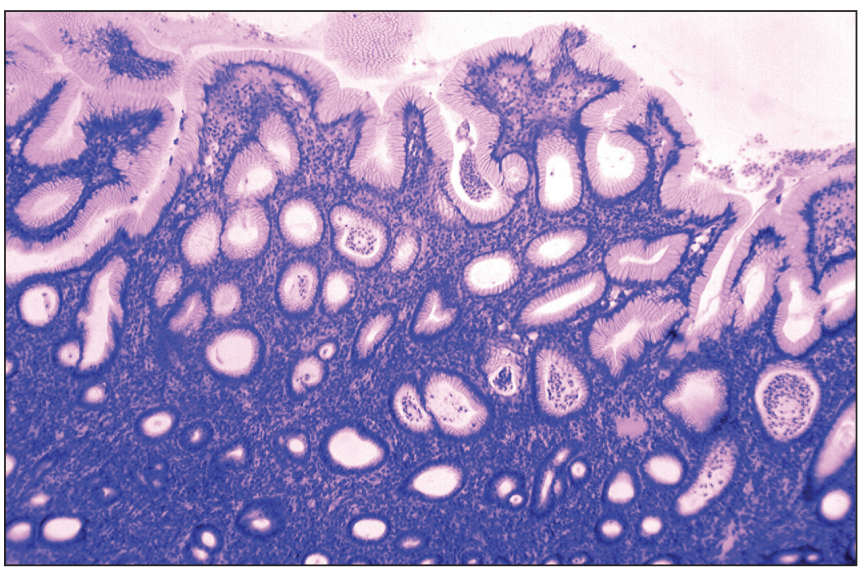

Fig.1. Atrophic gastritis.

In atrophic gastritis, the mucous membrane of the stomach has a normal thickness, the structure of the glands is preserved. There is some uneven depth of the gastric pits, the expansion of the foveolar layer of the mucous membrane. In the foveolar layer of varying severity, cellular, mainly lympho-plasmacytic infiltration, with a certain number of histiocytes and eosinophils. Changes in the superficial-patchy epithelium of the gastric mucosa are quite variable. In some cells, it is represented by tall cylindrical cells, in others it is flat. In terms of their structure, the cells are close to the cells that are observed in the normal mucous membrane only in the depth of the pits (Fig. 1). Their appearance on the lateral surfaces of the pits and tops of the rollers can be considered as a result of a delay in differentiation and translocation of the cells of the germinative zone.

In addition to the above, there are dystrophic changes in the covering-patchy epithelium with loss of transparency in the usual colors of the cytoplasm, which becomes grainy or vacuolated and not clearly contoured, and the nuclei shift to the surface and look polychromatic.

In areas of the gastric mucosa at the base of the rollers in the inflammatory infiltrate, which had a lympho-plasmacytic character, a certain number of polymorphonuclear leukocytes appeared, penetrated into the epithelial layer, as well as into the hole of the gastric pits

Helicobacter pylori is found in the gastric mucosa in $90 \%$ of cases. Bacteria rod-shaped or curved were placed under a layer of mucus within the pathogenic epithelium on the tops of the ridges, their lateral surface and deep in the dimples (Fig. 2).

Bacteria were found in all parts of the stomach, but a high degree of bacterial seeding was much more often observed

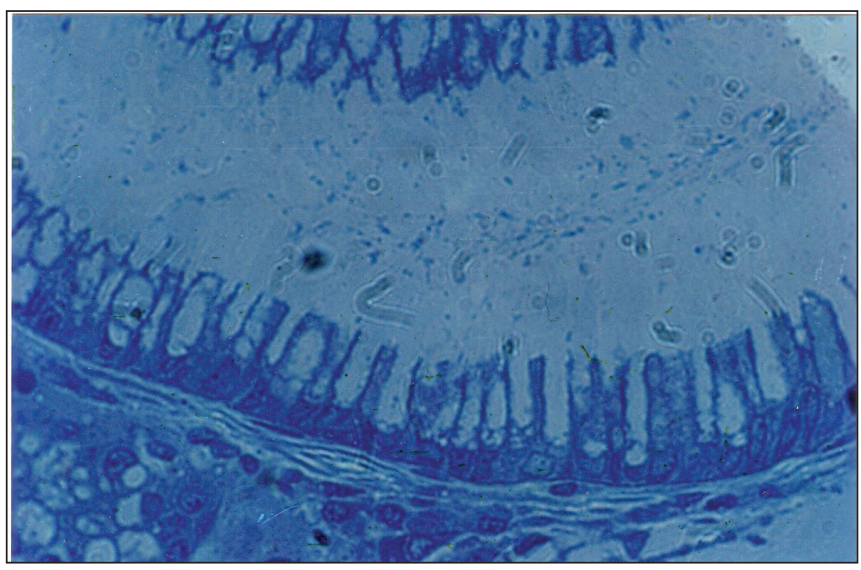

Fig. 2. Colonization of the bacteria Helicobacter pylori of the gastric mucosa. Bacteria deep in the gastric fossa. Half slice. Coloring toluidine blue. An increase of 600 .

in the mucous membrane of the pyloric part of the stomach (Fig. 3) and the lesser curvature (Fig. 4.), Compared to the mucous walls of the body $(42.0 \pm 100 \%$ and $14.0 \pm 6.0, p$ $<0.05$ ) (Figure 5, 6.).

Conversely, the low degree of infection of Helicobacter pylori was most often in the mucous membrane of the walls of the body of the stomach (Fig.5, 6), comparing with the mucous of the pyloric department and the lesser curvature $(40.0 \pm 10.0 \%$ and $16.0 \pm 6 \%, \mathrm{p}<0.05)$ (Fig. 3, 4.).

A moderate degree of contamination of the gastric mucosa of Helicobacter pylori in all parts of it met evenly. The intensity of the leukocyte infiltrate directly correlated with the degree of seeding of the mucous membrane of Helicobacter pylori (Fig. 3 - 6).

There is a tendency to reduce the degree of bacterial contamination of the gastric mucosa from its pyloric department and the lesser curvature to the walls of the body. With a decrease in the degree of bacterial contamination of the gastric mucosa, the degree of leukocyte infiltration also decreases.

Between the degree of contamination of the mucous membrane of Helicobacter pylori and the degree of leukocyte infiltration of the mucous membrane, the Pearson correlation coefficient $r_{x y}$ is 0.935 , the correlation is very strong, the determination coefficient is $\mathrm{D}=\mathrm{r}_{\mathrm{xy}} \wedge 2-0.874$, the critical value of the correlation coefficient with a probability of $0.95-0.2732$, the critical value of the correlation coefficient with a probability of $0.99-0.3511$, comparing the correlation coefficient $r_{x y}$ with a critical $r_{c r}$ value for $a$ significance of $0.95-r_{x y}>r_{c r}$, comparing the correlation coefficient $r_{x y}$ with a critical $r_{c r}$ value for a significance of 


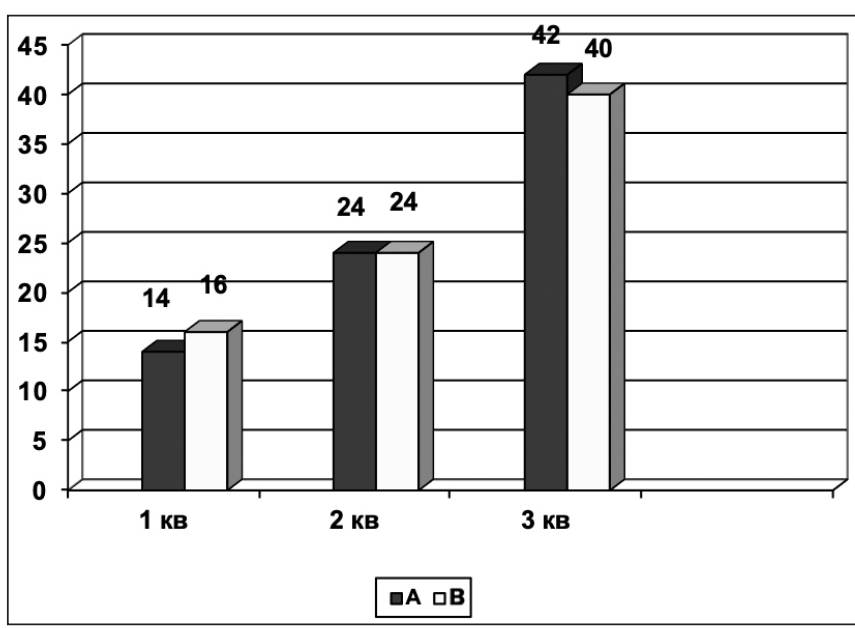

Fig. 3. Pyloric. A. The frequency of the various degrees of contamination of Helicobacter pylori of the gastric mucosa. B. Frequency of varying degrees of leukocyte infiltration: 10 - low, $2 Q$ - moderate, 30 - high degree in $\%$.

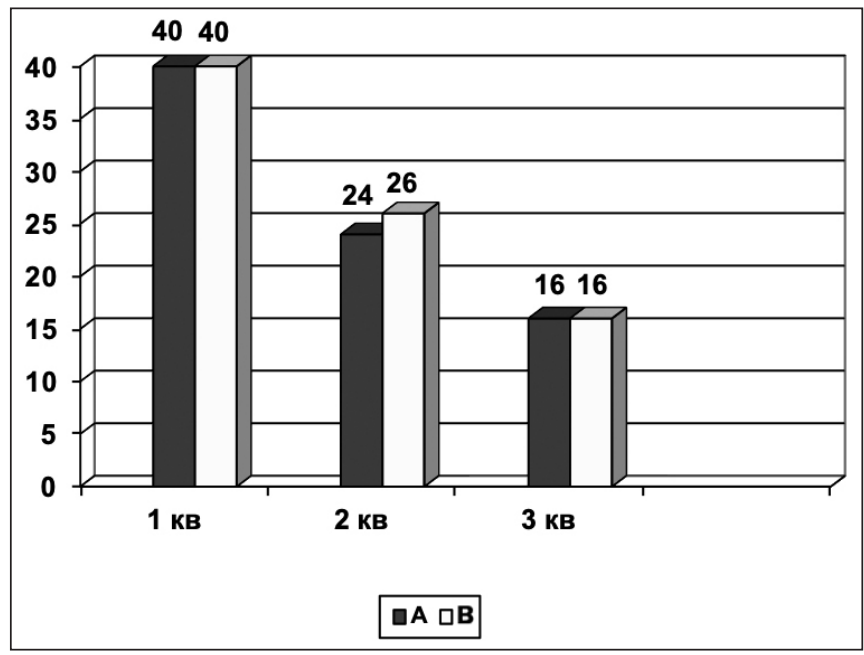

Fig. 5. The front wall of the body. A. The frequency of the various degrees of contamination of Helicobacter pylori of the gastric mucosa. B. Frequency of varying degrees of leukocyte infiltration: $1 \mathrm{kV}$ - low, $2 \mathrm{kV}$ - moderate, $3 \mathrm{kV}$ - high degree in percent (\%).

$0.99-r_{x y}>r_{c r}$ to the covariance coefficient is 521.641, this makes it possible to conclude a statistically significant dependence with a probability of 0.99 .

We consider it expedient, in discussing the results of our own research, to make a short theoretical discussion of this problem on the material of literary sources.

Central among pretumor diseases of the stomach is chronic gastritis, against the background of which and in connection with which precancerous changes occur. One of the etiological factors of chronic gastritis, peptic ulcer and gastric cancer is Helicobacter pylori. According to the recommendations of the WHO special committee, we distinguish between precancerous conditions and precancerous changes. Pre-cancerous conditions are diseases that increase the risk of cancer. Traditionally, chronic gastritis is referred to as precancerous conditions. But since 1994, Helikobakter pylori infection has been included in precancerous conditions [16].

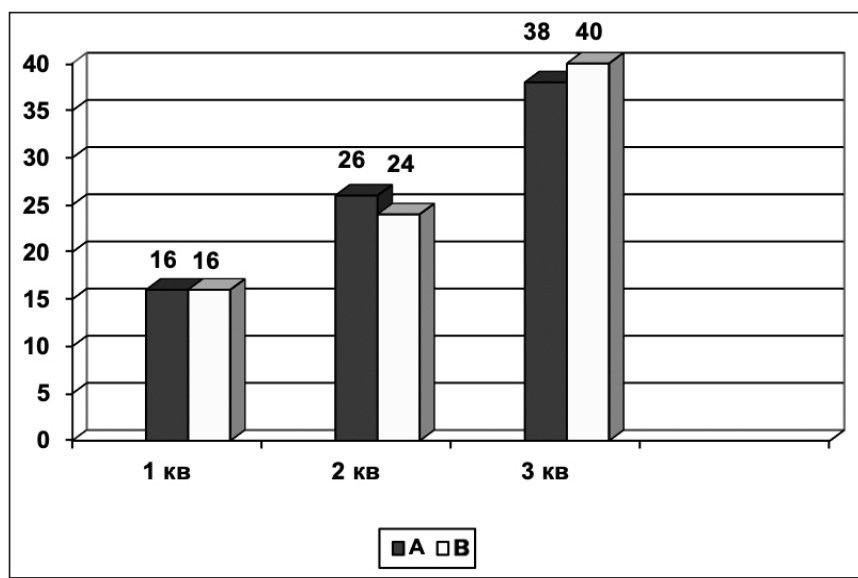

Fig. 4. Small curvature. A. The frequency of the various degrees of contamination of Helicobacter pylori of the gastric mucosa. B. Frequency of varying degrees of leukocyte infiltration: $1 \mathrm{kV}$ - low, $2 \mathrm{kV}$ - moderate, $3 \mathrm{kV}$ - high degree in percent (\%).

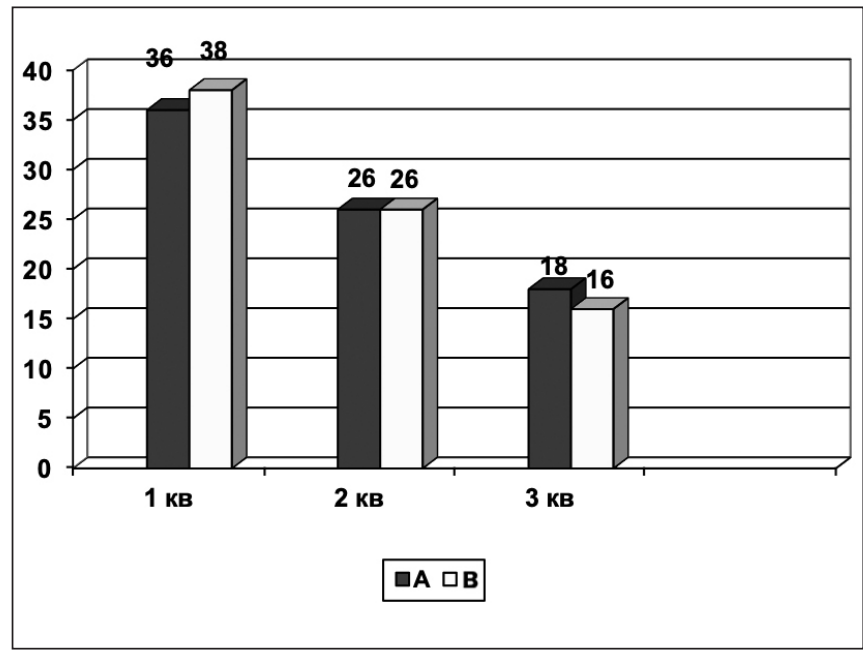

Fig.6. The back wall of the body. A. The frequency of the various degrees of contamination of Helicobacter pylori of the gastric mucosa. B. Frequency of varying degrees of leukocyte infiltration: $1 \mathrm{kV}$ - low, $2 \mathrm{kV}$ - moderate, $3 \mathrm{kV}$ - high degree in percent (\%).

Chronic gastritis is often found, especially among the population of young and working age, and represents an independent disease, or creates a background against which other diseases of the stomach develop, or accompanies them. A study by epidemiologists showed that gastric cancer in Helicobacter pylori infected people is more common than in non-infected people [17].

Cellular update is regulated on the basis of negative feedback on the loss of part of the population. It responds by increasing the neoplasm of cells and accelerating their migration. The reasons for reducing the population of epithelial cells can be their death on the spot and desquamation in the stomach cavity. As chronic gastritis progresses, more and more cells become in the S-phase, they even reach the tops of the rollers and can come into contact with carcinogens from the stomach cavity. Helicobacter pylori have the ability to stimulate cell renewal directly and by stimulating lymphocytes to synthesize relevant 
agents. In addition, Helicobacter gastritis usually leads to hypergastrinemia, which enhances the proliferation of the epithelium of the gastric [18].

In countries with a high risk of gastric cancer, the impression of the Helicobacter pylori epithelium of the gastric mucosa occurs already in early childhood, and this suggests that a long-term infection may be the cause of the progression of chronic gastritis to gastric cancer [19].

\section{CONCLUSIONS}

In the mucous membrane of the stomach, changes corresponding to atrophic or hyperplastic gastritis associated with HP were found, respectively, in $90 \%$ of cases. The degree of bacterial contamination correlates with the degree of leukocyte infiltration of the gastric mucosa with active gastritis. This confirms the view that pronounced atrophic or hyperplastic gastritis Helicobacter pylori-associated is a common disease in young and working age. What is troubling.

\section{REFERENCES}

1. Rugge M., Genta R. M. Staging and grading of chronic gastritis. Human Pathology. 2005; 36: 228-233.

2. Kharchenko 0.V. Porivnyalna kharakteristyka riznyh form khronichnogo gastrytu u pacientiv iz vyrazkoyu dvanadciatypaloi kyshki, shlunka ta vyrazkovo-infiltrativnym rakom shlunka. [Comparative characteristics of various forms of chronic gastritis in patients with duodenal ulcer, stomach and ulcer infiltrative cancer of the stomach.] World of medicine and biology. 2008; 4: 76-81. [in Ukrainian.]

3. Bizzozero G. Über die schlauchförmigen Drüsen des Magen-Darm-Kanals und die Bezichungen ihres Epithels zu dem Oberflächenepithel der Schleimhaut. Arch. Mikr. Anat. 1893; 42: 82-96.

4. Marshall B.J.,Warren J.R. Unidentifid curved bacilli on gastric epithelium in active chronic gastritis. Lancet. 1983; 1(8336): 1273-1275.

5. Kharchenko 0.V., Sherstyuk 0.A. Naslidky infekcyi Helicobacter pylori. [Effects of infection of Helicobacter pylori.] World of medicine and biology. 2018; 3: 196-199. [in Ukrainian.]

6. Kharchenko 0.V. Diagnostika peredpuhlynnyh zmin epiteliyu slyzovoyi obolonky shlunka za dopomogoyu gistologicnogo ta immunogistohimichnogo metodiv u khvoryh na khronichnu vyrazku dvanadciatypaloyi kishky. [Diagnostosis of pretumor changes in the epithelium of the gastric mucosa using histological and immunohistochemical methods in patients with duodenal ulcers.] Visnyk problem biologyi i mediciny. 2014;2 (3):289-294. [in Ukrainian]

7. Kharchenko 0.V. Vysoka informatyvnist molekulyarno-biologichnyh markeriv. [Highly informative molecular biological markers.] Visnyk problem biologyi i mediciny. 2014; 3(2): 26-30. [in Ukrainian]

8. Kharchenko O.V. Kompleksnaya immunogistohimicheskaya I molekulyarno-biologicheskaya diagnostika predopuholevyh processov slizistoy obolochki geludka. [Complex immune-histological and molecular-biological diagnostics of pretumor processes of the gastric mucosa.] Aktualni problemy suchasnoyi mediciny. 2014; 14 (2): 165170. [in Ukrainian]

9. Kharchenko 0.V. Microsatellitni ekspansyi - molekulyarno-biologichnyi fenomen diagnostiki peredpuhlynnyh i puhlynnyh procesiv. [Microsatellite expansion is a molecular-biological phenomenon in the diagnosis of pretumor and tumor processes.] World of medicine and biology. 2015; 2: 76-81. [in Ukrainian.]
10. Kharchenko 0.V. Nestabilnist microsatellitiv - material dlya formuvanya molekulyarno biologichnyh diagnostichnyh markeriv. [Microsatellite instability is a material for the formation of molecular biological diagnostic markers.] Biologiya ta ecologiya. 2016; 1: 87-93. [in Ukrainian]

11. Kostilenko J.P., Kovaliov E.V. Metody raboty s polutonkimi epoksidnymi srezami v gistologicheskoy praktike. [Methods of working with semithin epoxy sections in histological practice.] Arhiv anatomyi, gistologyi i embriologyi. 1978; 75 (12): 68-72. [in Russian]

12. Merkulov A.T. Kurs patologogistologicheskoy tehniki. [The course of the pathological technique.] L.: Medicina; 1969. 243p. [in Russian.]

13. Aruin L.I., Kononov A.V., Mozgovoy S.I. Mezdunarodnaya klassifikacia khronicheskogo gastrita: chto sleduet prinyati i chto vyzyvaet somnenya. [Medical classification of chronic gastritis: what should be taken with what is in doubt.] Arh. Pat. 2009; 4: 11-18. [in Russian.]

14. Tască C. Introducere in morfologia cantitativa cito-histologia. Bucuresti: Editura Academiei R.S.R., 1976, p191.

15. AvtandilovG.G. Osnovy kolichestvennoy patologicheskoy anatomii.[Basics of quantitative pathological anatomy] M.: Medicina, 2002, p240. [in Russian.]

16. Fritz A., Perey C., Jack A et al. WHO International Classification of Diseases for oncology ICD-0. 3 rd ed. Geneva: WHO, 2000.

17. S. Isajevs, I. Liepniece-Karele, D. Svirina, et al. Different Pattern of Inflammatory and Atrophic Changes in the Gastric Mucosa of the Greater and Lesser Curvature. J. Gastrointestin. Liver. Dis. 2015; 4: 429-434.

18. Hong L.I., Helander H.F. Hypergastrinemia increases proliferation of gastroduodenal epithelium. Dig. Dis. Sci. 1996; 41: 40 - 48.

19. Li U, Sya R, Chzhan B, Li S Chronic atrophic gastritis: review. Environ Pathol Toxicol Oncol. 2018; 37 (3): 241-259.

The work is a fragment of the research and development project "Realization of Health Savings Technologies in Physical Education in the Conditions of European Integration of Ukraine", state registration No. 0117 U003236.

\section{ORCID and contributionship:}

Aleksandr V. Kharchenko - 0000-0002-7822-9476 $6^{A, D, F}$

Nataliya V. Kharchenko - 0000-0001-8668-1596

Petro M. Makarenko - 0000-0002-8967-9122

Lyudmyla M. Sakharova - 0000-0001-6719-3239

Pavlo V. Khomenko - 0000-0003-3065-9095 ${ }^{E}$

Olga V. Kvak-0000-0002-3787-3433

\section{Conflicts of interest:}

Authors declare no conflict of interest.

\section{CORRESPONDING AUTHOR Oleksandr V. Kharchenko \\ Petro Mohyla Black Sea National University, \\ Mykolaiv, Ukraine \\ tel: +380507404749 \\ e-mail:kharchenk07591@gmail.com}

\author{
Received: 18.04 .2019 \\ Accepted: 27.11 .2019
}

A - Work concept and design, B - Data collection and analysis, C - Responsibility for statistical analysis,

$\mathbf{D}$-Writing the article, $\mathbf{E}-$ Critical review, $\mathbf{F}-$ Final approval of the article 